\title{
Novel Active Food Packaging Films Based on Whey Protein Incorporated with Seaweed Extract: Development, Characterization, and Application in Fresh Poultry Meat
}

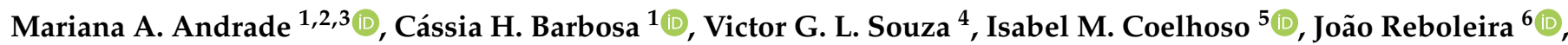 \\ Susana Bernardino ${ }^{6}$, Rui Ganhão ${ }^{6}\left(\mathbb{D}\right.$, Susana Mendes ${ }^{6} \mathbb{D}$, Ana Luísa Fernando ${ }^{4}\left(\mathbb{D}\right.$, Fernanda Vilarinho ${ }^{1}(\mathbb{D}$, \\ Ana Sanches Silva ${ }^{7,8, *(D)}$ and Fernando Ramos 2,3 (D) \\ 1 Department of Food and Nutrition, National Institute of Health Dr. Ricardo Jorge, Av. Padre Cruz, \\ 1649-016 Lisbon, Portugal; mariana.andrade@insa.min-saude.pt (M.A.A.); \\ cassia.barbosa@insa.min-saude.pt (C.H.B.); fernanda.vilarinho@insa.min-saude.pt (F.V.) \\ 2 Faculty of Pharmacy, University of Coimbra, Azinhaga de Santa Comba, 3000-548 Coimbra, Portugal; \\ framos@ff.uc.pt \\ 3 REQUIMTE/LAQV, R. D. Manuel II, Apartado, 55142 Oporto, Portugal \\ 4 MEtRICs, Departamento de Ciências e Tecnologia da Biomassa, NOVA School of Science and \\ Technology I FCT NOVA, Universidade NOVA de Lisboa, Campus de Caparica, 2829-516 Caparica, Portugal; \\ victorlauriano@yahoo.com.br (V.G.L.S.); ala@fct.unl.pt (A.L.F.) \\ check for \\ updates \\ Citation: Andrade, M.A.; Barbosa, \\ C.H.; Souza, V.G.L.; Coelhoso, I.M.; \\ Reboleira, J.; Bernardino, S.; Ganhão, \\ R.; Mendes, S.; Fernando, A.L.; \\ Vilarinho, F.; et al. Novel Active Food \\ Packaging Films Based on Whey \\ 5 LAQV-REQUIMTE, Departamento de Química, NOVA School of Science and Technology I FCT NOVA, \\ Universidade NOVA de Lisboa, Campus de Caparica, 2829-516 Caparica, Portugal; imrc@fct.unl.pt \\ 6 MARE-Marine and Environmental Sciences Centre, School of Tourism and Maritime Technology, \\ Poly-technic of Leiria, 2520-208 Peniche, Portugal; joaoreboleira@gmail.com (J.R.); \\ susana.bernardino@ipleiria.pt (S.B.); rganhao@ipleiria.pt (R.G.); susana.mendes@ipleiria.pt (S.M.) \\ 7 National Institute for Agricultural and Veterinary Research (INIAV), I.P., Rua dos Lagidos, Lugar da \\ Ma-dalena, Vairão, 4485-655 Vila do Conde, Portugal \\ 8 Center for Study in Animal Science (CECA), ICETA, University of Oporto, 55142 Oporto, Portugal \\ * Correspondence: ana.silva@iniav.pt
} Protein Incorporated with Seaweed Extract: Development, Characterization, and Application in Fresh Poultry Meat. Coatings 2021, 11, 229. https://doi.org/10.3390/ coatings11020229

Academic Editor: Stefano Farris

Received: 7 January 2021

Accepted: 9 February 2021

Published: 14 February 2021

Publisher's Note: MDPI stays neutral with regard to jurisdictional claims in published maps and institutional affiliations.

Copyright: (C) 2021 by the authors Licensee MDPI, Basel, Switzerland. This article is an open access article distributed under the terms and conditions of the Creative Commons Attribution (CC BY) license (https:// creativecommons.org/licenses/by/ $4.0 /)$.
Abstract: Algae and seaweeds are used in cookery since the beginnings of human civilization, particularly in several Asian cultures. Phenolic compounds are secondary metabolites produced by aquatic and terrestrial plants for their natural defense against external stimuli, which possess powerful antimicrobial and antioxidant properties that can be very important for the food industry. The main objective of this study was to develop a whey protein concentrate active coating, incorporated with a Fucus vesiculosus extract in order to delay the lipid oxidation of chicken breasts. Ten hydroethanolic extracts from F. vesiculosus were obtained and their antioxidant capacity was evaluated through two antioxidant activity assays: the DPPH radical scavenging activity and $\beta$-carotene bleaching assay. The total content in phenolics compounds was also determined by Folin-Ciocalteu method. The chosen extract was the one obtained from the freeze-dried F. vesiculosus using $75 \%(v / v)$ ethanol as extraction solvent. The extract was successfully incorporated into a whey protein film and successfully strengthened the thickness, tensile strength, and elastic modulus. The active film also was able to inhibit the chicken breasts lipid oxidation for 25 days of storage.

Keywords: seaweed; Fucus vesiculosus; active packaging; natural extracts; lipid oxidation; algae

\section{Introduction}

Since the early stages of the human civilization, seaweeds are part of the traditional gastronomies of several Asian countries. Nutritionally, these type of plants are characterized for having a low fat content and a mineral content higher than the terrestrial plants, being a good matrix to be used for nutritional supplements in order to overcome some nutritional deficiencies [1-4]. Human consumption of seaweeds and algae is very common in the Asian culture, especially in Japan. In the Asian gastronomy, several species are 
consumed as seasonings and vegetables, which contribute for a diversification on their diet. On the other hand, recently, seaweeds and algae in Europe are used for supplementation or for industrial applications such as gelling agents $[5,6]$.

Terrestrial and aquatic plants, for their defense against UV radication, pathogenic organisms, predators and parasites, naturally produce secondary metabolites known as phenolic compounds. These compounds are also responsible for the plants' coloration and organoleptic properties [7-11]. Moreover, the bioactivity of plants, namely antioxidant and antimicrobial properties, are related to their content in phenolic compounds. The content in phenolic compounds depends on the plant's edaphoclimatic characteristics, such as the soil, the geographical location, the moment of harvest, among others [10,12-14]. These active compounds can be obtained in the form of essential oil or extract through several extraction methods that can be applied to fresh, dried or freeze-dried plants and fruits.

Fucus vesiculosus is a brown edible seaweed (Class Phaeophyceae), known for its high iodine content and can be easily found in the tempered and cold zones of the North Atlantic [15-17]. The deficiency of iodine is a very serious issue once it can lead to serious conditions. Iodine is a micronutrient essential during the gestation period and for the proper functioning of the thyroid. This deficiency can cause neonatal death, decrease of intellectual development in children and can lead to infertility. The World Health Organization (WHO) recommends a diary intake of $150 \mu \mathrm{g} /$ day for adults and 200-300 $\mu \mathrm{g} /$ day during the gestation period [18-20]. Although it is mainly under control in the first world countries, iodine deficiency still represents an important issue in undeveloped countries besides being the major preventable cause of brain damage in the world. In this vision, the WHO has set a goal to end iodine deficiency by $2020[19,20]$. Considering its high content in iodine and phytosterols, F. vesiculosus was recommended for obesity treatment. Although, this recommendation is no longer valid because of the secondary effects of iodine on the thyroid activity when treatment stops [21].

Food packaging main goal is to delay the foods' natural degradation process, maintaining their organoleptic properties, protecting the packaged food during transportation and storage. With the advancement of technology, new packaging systems have emerged, such as active food packaging. This type of packaging, by direct interaction with the packaged food throughout the absortion or releasing systems, aims to prolong foods' shelf-life maintaining or improving its organoleptic properties [22-25]. The releasing systems, as the name implies, release active compounds or substances to the packaged food with biological activities, such as antimicrobial or antioxidant [22,26]. Extracts and essential oils from aromatic plants, fruits by-products and seaweeds have powerful antioxidant activities due to their high content in phenolic compounds [27].

Till this day, lipid oxidation is one of the major causes of food spoilage and, consequently, originates high amount of food loss [28-30]. This natural occurring phenomenon can lead to molecular changes in foods, changes in foods' nutritional value and formation of unpleasant tastes and/or aromas which, subsequently will reduce foods' shelflife $[28,30,31]$. Active food packaging incorporated with antioxidant substances can help to minimize this problem, which will gradually migrate to the food' surface during storage time [31-36].

The objective of this study was to evaluate the antioxidant activity of ten hydroethanolic extracts obtained from $F$. vesiculosus L., and to incorporate the extract with the highest antioxidant capacity into a whey protein film as an active packaging to control lipid oxidation of chicken breasts.

\section{Materials and Methods}

\subsection{Extract Production}

F. vesiculosus was acquired from the Portuguese company, ALGAPlus ${ }^{\mathrm{TM}}$, Illhavo, Portugal. The seaweed was washed three times in cold running tap water to removed most of the salt and possible impurities. One part of the seaweed was frozen and freeze-dried in a 
freeze drier (Heto PowerDry PL 9000, Thermo Fisher Scientific ${ }^{\mathrm{TM}}$, Waltham, MA, USA) and the other part was dried in an oven at $30^{\circ} \mathrm{C}$ for 10 days, in the dark.

Five hydroethanolic solvents were used: $100 \%$ ethanol, $75 \%$ ethanol, $50 \%$ ethanol, $25 \%$ ethanol and $100 \%$ water. For the extraction process, the method described by Andrade et al. [37] was used. Briefly, to $5 \mathrm{~g}$ of the freeze-dried or the dried seaweed, $50 \mathrm{~mL}$ of solvent were added and homogenized for $30 \mathrm{~min}$ in a compact stirrer (Edmund Bühler ${ }^{\mathrm{TM}}$ Shaker KS $15 \mathrm{~A}$, Hechingen, Germany) at $350 \mathrm{rpm}$. Then, the mixtures were centrifuged for $10 \mathrm{~min}$ at $2000 \mathrm{~g}(10,000 \mathrm{rpm})$ (Eppendorf AG 5804R, Hamburg, Germany). The supernatant was removed to an evaporation amber pear-shaped flask and ethanol was evaporated at $35^{\circ} \mathrm{C}$. The extracts with water were then frozen and freeze-dried.

\subsection{Antioxidant Capacity Assays}

For the antioxidant capacity assays, all the extracts were tested at $5 \mathrm{mg} / \mathrm{mL}$ with the exception of the $100 \%$ ethanolic extracts that were tested at $1 \mathrm{mg} / \mathrm{mL}$ due to their low yield (Table 1).

Table 1. Seaweed extracts antioxidant properties characterization. Results are the means \pm standard deviation of the replicants.

\begin{tabular}{|c|c|c|c|c|c|c|c|c|}
\hline \multirow{2}{*}{ Solvent } & \multicolumn{2}{|c|}{ Yield (\%) } & \multicolumn{2}{|c|}{ IP (\%) } & \multicolumn{2}{|c|}{$\begin{array}{c}\beta \text {-Carotene Assay } \\
\text { (AAC) }\end{array}$} & \multicolumn{2}{|c|}{$\begin{array}{c}\text { TPC Assay } \\
\text { (mg PGE/g of Extract) }\end{array}$} \\
\hline & FD & D & FD & D & FD & $\mathbf{F}$ & FD & $\mathrm{D}$ \\
\hline $\begin{array}{c}100 \% \\
\mathrm{H}_{2} \mathrm{O}\end{array}$ & 18.63 & 26.66 & $62.51 \pm 0.17^{\mathrm{Ca}}$ & $0.00^{\mathrm{Cb}}$ & $842.67 \pm 5.55^{\mathrm{Aa}}$ & $575.10 \pm 10.64^{\mathrm{Bb}}$ & $26.18 \pm 0.11$ Еa & $19.03 \pm 0.10^{\mathrm{Cb}}$ \\
\hline $\begin{array}{c}25 \% \\
\text { Ethanol }\end{array}$ & 20.02 & 21.38 & $66.69 \pm 0.33^{\mathrm{Ba}}$ & $17.88 \pm 0.79 \mathrm{Bb}$ & $356.07 \pm 6.42^{\mathrm{Da}}$ & $250.76 \pm 5.31^{\mathrm{Db}}$ & $27.05 \pm 0.31^{\mathrm{Da}}$ & $16.18 \pm 0.09 \mathrm{Db}$ \\
\hline $\begin{array}{c}50 \% \\
\text { Ethanol }\end{array}$ & 13.09 & 22.30 & $57.00 \pm 0.47^{\mathrm{Da}}$ & $16.33 \pm 0.86^{\mathrm{Bb}}$ & $564.59 \pm 11.06^{\mathrm{Ca}}$ & $383.24 \pm 7.07^{\mathrm{Cb}}$ & $31.12 \pm 0.26^{\mathrm{Ca}}$ & $12.42 \pm 0.11^{\mathrm{Eb}}$ \\
\hline $\begin{array}{l}75 \% \\
\text { Ethanol }\end{array}$ & 4.71 & 18.77 & $78.26 \pm 0.21 \mathrm{Aa}$ & $57.44 \pm 0.99 \mathrm{Ab}$ & $636.22 \pm 5.16^{\mathrm{Ba}}$ & $611.91 \pm 8.09 \mathrm{Ab}$ & $45.21 \pm 0.21^{\mathrm{Ba}}$ & $21.06 \pm 0.12^{\mathrm{Bb}}$ \\
\hline $\begin{array}{l}100 \% \\
\text { Ethanol }\end{array}$ & 2.71 & 3.86 & $44.65 \pm 0.79 \mathrm{Ea}$ & $0.86 \pm 0.03^{\mathrm{Cb}}$ & $237.82 \pm 5.03$ Еa & $125.36 \pm 11.90^{\mathrm{Eb}}$ & $194.65 \pm 0.87 \mathrm{Aa}$ & $70.97 \pm 0.74^{\mathrm{Ab}}$ \\
\hline
\end{tabular}

Legend: FD-Freeze-dried; D-Dried; IP-Inhibition Percentage; AAC-Antioxidant Activity Coefficient; TPC-Total Phenolic Compounds; PGE-Phloroglucinol equivalents. (A-E): Within each parameter, values in the same column not sharing upper case superscript letters indicate statistically significant differences among solvents $(p<0.05)$; $(\mathrm{a}-\mathrm{b})$ : Within each parameter, values in the same line not sharing lower case superscript letters indicate statistically significant differences among formulations $(p<0.05)$.

\subsubsection{DPPH Radical Scavenging Assay}

The antioxidant capacity of the ten hydroethanolic extracts was evaluated through the DPPH radical scavenging assay by the method described by Andrade et al. [37]. To $50 \mu \mathrm{L}$ of sample, $2 \mathrm{~mL}$ of a methanolic solution of the DPPH radical $(14.2 \mu \mathrm{g} / \mathrm{mL})$ were added. The samples were homogenized and kept in the dark, for $30 \mathrm{~min}$, at room temperature $\left(23 \pm 1{ }^{\circ} \mathrm{C}\right)$. The absorbance of the samples was measured at $515 \mathrm{~nm}$ in a Thermo Scientific Evolution $300 \mathrm{LC}$ spectrophotometer. For the control samples $50 \mu \mathrm{L}$ of the used solvent were used. The Inhibition Percentage (IP) was calculated by the Equation (1).

$$
I P(\%)=\frac{A C-A S}{A C} \times 100
$$

In which, $A C$ stands for the absorbance of the control samples and the $A S$ stands for the absorbance of the samples.

\subsection{2. $\beta$-Carotene Bleaching Assay}

The method applied in this study was initial described by Miller [38] and adapted by Andrade et al. [37]. To prepare the $\beta$-carotene and linoleic acid emulsion, $1 \mathrm{~mL}$ of a $\beta$-carotene in chloroform solution $(2 \mathrm{mg} / \mathrm{mL}), 20 \mathrm{mg}$ of linoleic acid and $200 \mathrm{mg}$ of Tween ${ }^{\circledR}$ 40 were mixed in an amber evaporation flask. Then, the chloroform was evaporated in a rotary evaporator at $40{ }^{\circ} \mathrm{C}$, for $5 \mathrm{~min}$, and $50 \mathrm{~mL}$ of ultra-pure water, obtained from a 
MilliQ $^{\mathrm{TM}}$ filter system, were added and the solution was strongly shaken. Then, $5 \mathrm{~mL}$ of the emulsion were added to $200 \mu \mathrm{L}$ of sample. For the control assays, $200 \mu \mathrm{L}$ of solvent were used and the absorbance of the controls was measured at $470 \mathrm{~nm}$. Then the controls and the samples were submitted at $50{ }^{\circ} \mathrm{C}$ for $2 \mathrm{~h}$. At the end of this period, the absorbance of the samples and the controls were measured at $470 \mathrm{~nm}$. The Antioxidant Activity Coefficient (AAC) was measured through the Equation (2).

$$
A A C=\frac{A S-A C 2}{A C 0-A C 2} \times 1000
$$

wherein, $A S$ stands for the absorbance of the sample, $A C 0$ stands for the absorbance of the control before heating and $A C 2$ stands for the absorbance of the control after heating.

\subsection{Total Phenolic Compounds (TPC)}

The total content on Phenolic Compounds was determined through the method described by Wang et al. [39]. Briefly, to $1 \mathrm{~mL}$ of sample, $5 \mathrm{~mL}$ of an aqueous solution of Folin-Ciocalteu $(10 \%, v / v)$ was added. The mixture was homogenized and, after $5 \mathrm{~min}$, $4 \mathrm{~mL}$ of an aqueous solution of sodium carbonate $(7.5 \%, w / v)$ were added. The mixtures were homogenized and kept in the dark for $2 \mathrm{~h}$, at room temperature $\left(23 \pm 1{ }^{\circ} \mathrm{C}\right)$. The samples absorbance was measured at $725 \mathrm{~nm}$. The results are expressed in mg equivalents of phloroglucinol per $\mathrm{g}$ of extract.

\subsection{Whey Protein Film Production}

The active film was produced by casting, applying the method described by Andrade et al. [37] and is composed by $8 \%$ of concentrated whey protein, $8 \%$ of glycerol, $1 \%$ of $F$. vesiculosus L. extract and $83 \%$ of water. The whey protein concentrated was acquired from MyProtein ${ }^{\circledR}$ (Chicago, IL, USA). Briefly, the whey protein was mixed with water using an Ultra-Turrax (IKA DI 25 basic, Werke GmbH \& Co., Staufen im Breisgau, Germany) and then submitted to $80^{\circ} \mathrm{C}$ for $30 \mathrm{~min}$ in a thermostatic bath. Then, the mixture was rapidly cooled in ice for $15 \mathrm{~min}$. Glycerol and F. vesiculosus L. extract were added, homogenized with the Ultra-Turrax and casted in an aluminum foil surface. The film was left to dry for 3 to 4 days, at room temperature.

\subsection{Film Mechanical Properties and Thickness}

The films thicknesses was measured with a digital micrometer (0.001 mm, Mitutoyo, Japan) on ten randomly points of each sample, and the results were expressed by the means \pm standard deviation.

The film mechanical properties (tensile strength, elastic modulus and elongation at break) were determined using the universal testing machine Shimadzu Autoghaph (Shimadzu, Australia), equipped with a $0.5 \mathrm{kN}$ load cell, in accordance with ASTM D88212 [40]. Five specimens of each repetition/treatment with dimensions of $150 \times 25 \mathrm{~mm}^{2}$ were evaluated using the grip separation speed of $50 \mathrm{~mm} / \mathrm{min}$ and an initial gauge length of $50 \mathrm{~mm}$. The mechanical parameters were calculated from the stress $\times$ strain curves, where the tensile strength (TS) corresponds to the maximum stress before breaking (i.e., the force divided by the area in which the traction is applied), the elastic modulus (EM) represents the slope of the straight-line portion of a stress-strain curve and the percentage of elongation at break (EAB) is the ratio between the stroke before breakage (maximum elongation) and the initial distance between grips [41].

\subsection{Water Vapor Permeability (WVP)}

Water vapor permeability (WVP) (mol/m.s.Pa) was obtained, at $30^{\circ} \mathrm{C}$, using the gravimetric method described by Ferreira et al. [42]. Samples of each film were sealed on top of glass cells ( $45 \mathrm{~mm}$ diameter) containing $8 \mathrm{~mL}$ of supersaturated $\mathrm{NaCl}$ solution (relative humidity $(R H=76.9 \%)$. The cells were then placed inside desiccators containing supersaturated $\mathrm{CH}_{3} \mathrm{COOK}$ solution $(\mathrm{RH}=22.5 \%)$ and equipped with a fan to promote air circulation 
and keep the driving force constant throughout the test. Prior to the test, the films were equilibrated in a desiccator containing supersaturated $\mathrm{NaCl}$ solution $(\mathrm{RH}=76.9 \%)$ at $30^{\circ} \mathrm{C}$. The relative humidity and temperature of the inside air of the desiccators were monitored throughout the test using a thermo-hygrometer (Vaisala, Finland). The flow of water vapor was determined by weighing the cells at regular time intervals for approximately $22 \mathrm{~h}$, and the WVP was calculated using Equation (3):

$$
W V P=\frac{N_{W} \times \delta}{\Delta P_{w . e f f}}
$$

where Nw $\left(\mathrm{mol} / \mathrm{m}^{2} \cdot \mathrm{s}\right)$ corresponds to the flow of water vapor, $\delta(\mathrm{m})$ to the thickness of the film and $\Delta \mathrm{Pw}$.eff $(\mathrm{Pa})$ to the effective driving force. The results were expressed as the mean \pm standard deviation of three replicates.

\subsection{Film Optical Properties}

The optical properties were evaluated by measuring the CIELab parameters $\mathrm{L}, \mathrm{a}^{*}, \mathrm{~b}^{*}$, using the Konica Minolta colorimeter (CR 400/410, Tokyo, Japan) with D 65 light source, and $10^{\circ}$ visual angle. The analysis was conducted according to the CIELab color scale, where $\mathrm{L}$ is the measure of luminosity, ranging from zero (black) to 100 (white); $\mathrm{a}^{*}$ the chromaticity of green $(-60)$ to red $(+60)$; and $b^{*}$ the chromaticity of blue $(-60)$ to yellow $(+60)$. From the $\mathrm{L}, \mathrm{a}^{*}$ and $\mathrm{b}^{*}$ coordinates, the hue angle (hue $\mathrm{e}^{*}$ ) and chromaticity were calculated using Equations (4) and (5) respectively.

$$
\begin{gathered}
\text { hue }=\arctan \left(\frac{b^{*}}{a^{*}}\right) \times \frac{180}{\pi}+180, \text { if } a^{*}<0 \\
\text { chromaticity }=\left(a^{* 2}+b^{* 2}\right)^{1 / 2}
\end{gathered}
$$

\subsection{Evaluation of the Lipid Oxidation}

The chosen model food for the evaluation of the efficacy of the active package against lipid oxidation was chicken breast, which were kindly supplied by the Portuguese company, Lusiaves $^{\circledR}$ (Leiria, Portugal). The chicken breasts were packaged with the control (without the extract) and the active films, respectively, and stored at $4 \pm 1{ }^{\circ} \mathrm{C}$. To maximize the contact surface between the chicken breast and the active package, the samples were vacuum packaged (Figure 1). The chicken breasts were analyzed at the end of 3, 6, 8, 11, 15, 21 and 25 days of storage.

Thiobarbituric Reactive Substances Assay (TBARS)

The TBARS assay was performed according to the method described by Rosmini et al. [43] with minor changes. In brief, $10 \mathrm{~g}$ of minced chicken breasts were mixed with $20 \mathrm{~mL}$ of trichloroacetic acid $(7.5 \%, w / v)$ and homogenized in a compact stirrer at 400-450 rpm. After $1 \mathrm{~h}$, the solutions were filtered through a Whatman $n^{\circ} 1$ paper filter. Then, $5 \mathrm{~mL}$ of the filtered samples were mixed with $5 \mathrm{~mL}$ of an aqueous solution of thiobarbituric acid $(2.88 \mathrm{mg} / \mathrm{mL}, w / v)$. The solutions were homogenized and submitted to $95^{\circ} \mathrm{C}$ for $30 \mathrm{~min}$. Then, they were rapidly cooled in ice for $15 \mathrm{~min}$ and their absorbance was measured at $530 \mathrm{~nm}$. The results are present in $\mathrm{mg}$ of malonaldehyde equivalents per $\mathrm{kg}$ of meat. 

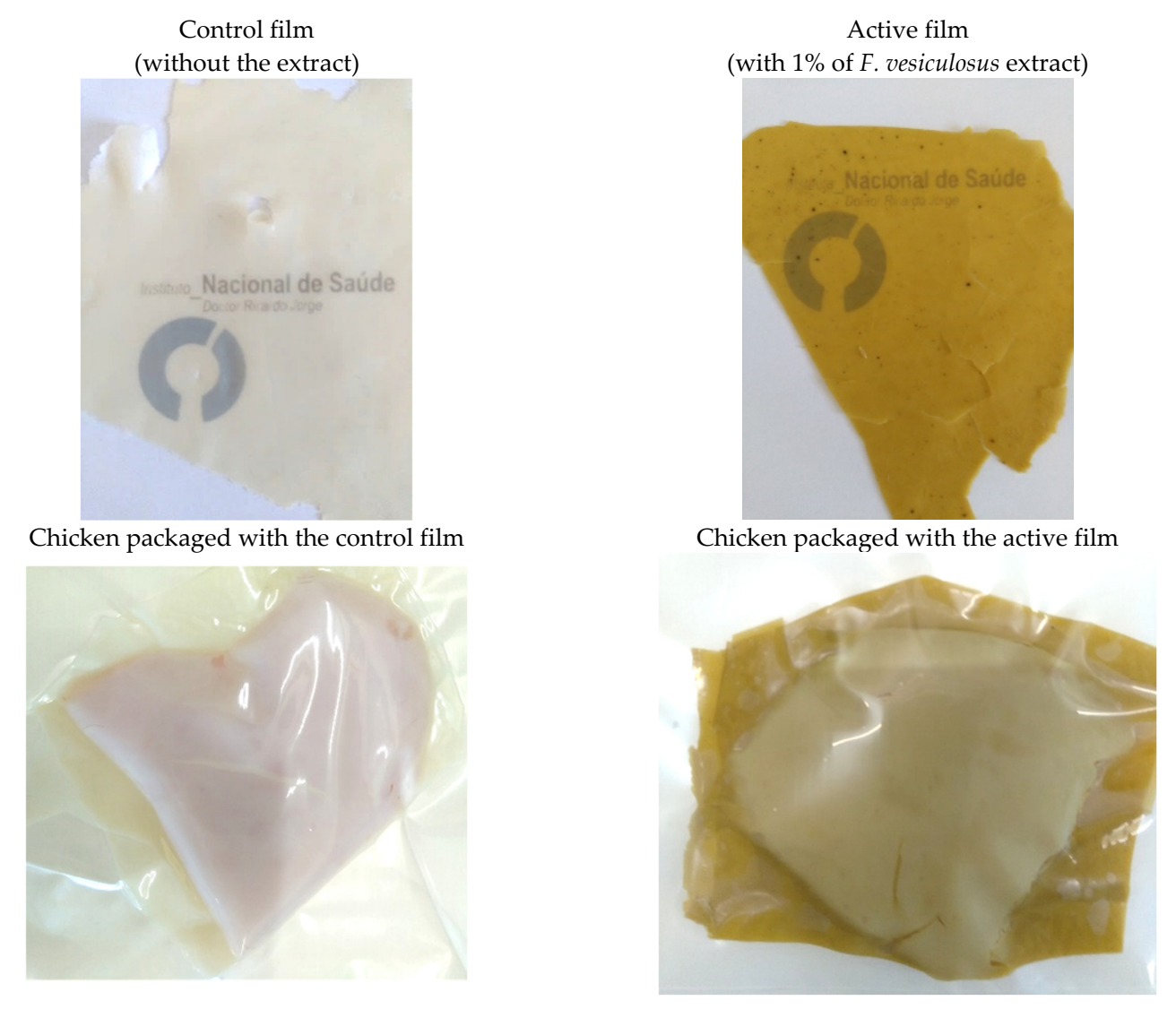

Figure 1. Control film (left) and active film with $1 \%$ of $F$. vesiculosus extract (right).

\subsection{Statistical Analysis}

All experiments were conducted using three replications. Statistical analysis of data was performed through a one-way analysis of variance (ANOVA) using the Software OriginLab, version 8.5 (OriginLab Corporation, Northampton, USA). The differences among mean values were processed by the Tukey test. All requirements necessary to carry out the ANOVA (namely, normality of data and homogeneity of variances) have been validated. Significance was defined at $p<0.05$. Results are expressed as the means of the replicants \pm standard deviation.

\section{Results}

\subsection{Antioxidant Assays}

The results of the antioxidant assays can be observed in Table 1. All the obtained extracts from the freeze-dried seaweed presented a significantly better antioxidant capacity results than the extracts obtained from the dried seaweed, probably because the freezedrying process protected the seaweed bioactive compounds [44,45].

As expected, the extracts obtained with a higher ethanol percentage, presented the lowest yields. Additionally, the extracts obtained from the dried seaweed, presented higher yields than the extracts obtained from the freeze-dried seaweeds. The extract obtained with the $75 \%$ ethanol presented the highest inhibition of the DPPH radical percentage, followed by the extract obtained with $25 \%$ ethanol. On the $\beta$-Carotene Bleaching Assay, the $100 \%$ aqueous extract presented the highest antioxidant activity coefficient, followed by the $75 \%$ ethanol extract. Regarding the total phenolic compounds content, the value obtained for the $100 \%$ ethanol extract was the highest, followed by the extract obtained by ethanol at $75 \%$.

Based on extraction yields and antioxidant assays results, the extract obtained from the freeze-dried F. vesiculosus $\mathrm{L}$. with $75 \%$ ethanol was chosen to be incorporated into the whey protein concentrate film. 


\subsection{Active Whey Protein Film}

The control and the active film can be observed above a paper sheet with the National Institute of Health Doutor Ricardo Jorge logo and applied to the chicken breasts (Figure 1).

\subsubsection{Thickness, Mechanical Properties, Optical Properties and WVP}

The addition of the $F$. vesiculosus extract seems to significantly increase the thickness of the control film in, approximately, $12 \%(p<0.05)$, which is coherent with the greater solid content per surface unit (Table 2). Regarding the other parameters, there were no significant differences, nevertheless, the addition of the $F$. vesiculosus extract seems to slightly reinforce some of the film' physical properties. When compared to the control film (Table 2), the active film presented a higher value of tensile strength and elastic modulus which, in consequence, decreased the elongation at break (elasticity of the film). However, the extract addition seemed to increase the WVP of the film, since the active film collapsed in the first hours of the essay, which indicates that the extract addition made the films more hydrophilic. Fernandes et al. (2020) [46] also found a similar WVP value for a whey protein film with $30 \%$ of glycerol. The addition of glycerol appears to increase the WVP of whey protein films. Ribeiro-Santos et al. (2018) [26] used the same percentage of glycerol and found similar results for the control film. Once the samples with seaweed extract collapsed during the test, it is impossible to conclude whether it enhanced or diminished the film's WVP, however as previously mentioned it probably enhanced the WVP, which corroborates with observed in Ribeiro-Santos et al. (2018) with the incorporation of a mixture of essential oils to whey protein films [26]. Gounga et al. (2007) [47] studied the influence of different whey protein and glycerol ratios on films' WVP. The authors concluded that a higher percentage of whey protein increase the WVP and also, the higher the glycerol percentage (plasticizing effect), the higher the WVP [47].

Table 2. Film characterization. Results are the means \pm standard deviation of the replicants.

\begin{tabular}{|c|c|c|}
\hline Parameter & Control Film & Active Film \\
\hline Thickness $(\mu \mathrm{m})$ & $248.8 \pm 6.7^{\operatorname{sig} * *}$ & $280.7 \pm 7.5^{\text {sig }}$ \\
\hline Tensile strength $(\mathrm{MPa})$ & $0.184 \pm 0.022^{\mathrm{ns}}$ & $0.203 \pm 0.055^{\mathrm{ns}}$ \\
\hline Elongation at break (\%) & $11.7 \pm 2.5^{\mathrm{ns}}$ & $8.7 \pm 1.9^{\mathrm{ns}}$ \\
\hline Elastic Modulus (MPa) & $1.468 \pm 0.617^{\mathrm{ns}}$ & $3.364 \pm 1.300^{\mathrm{ns}}$ \\
\hline $\mathrm{WVP}\left(10^{-10} \mathrm{~mol} / \mathrm{m} \cdot \mathrm{s} \cdot \mathrm{Pa}\right)$ & $1.178 \pm 0.21$ & Sample collapsed \\
\hline $\mathrm{L}^{*}$ (lightness) & $84.51 \pm 0.35^{\mathrm{sig}}$ & $60.72 \pm 0.19$ sig \\
\hline$a^{*}[$ red $(+a)$ or green $(-a)]$ & $-2.89 \pm 0.02$ sig & $-1.33 \pm 0.02^{\text {sig }}$ \\
\hline$b^{*}$ [yellow $(+b)$ or blue $\left.(-b)\right]$ & $13.14 \pm 0.66^{\text {sig }}$ & $23.50 \pm 0.03$ sig \\
\hline Hue $^{*}$ & $102.42 \pm 0.67^{\mathrm{sig}}$ & $93.25 \pm 0.05^{\mathrm{sig}}$ \\
\hline Chromaticity & $13.46 \pm 0.64 \mathrm{sig}$ & $23.54 \pm 0.03$ sig \\
\hline
\end{tabular}

** Means followed by sig superscripts are statistically significant different $(p<0.05)$; ns (not significant).

Comparing with the results obtained by Ribeiro-Santos et al. (2018) [26], the whey protein film presented the same behavior, in terms of thickness and elongation at break, in the presence of an additive. In both studies, the addition of extract and essential oils seemed to thicken the film, as well as increase the tensile strength. Abdalrazeq et al. (2019) [48] studied the application of different percentages (40 and 50\%, w/w) of glycerol into isolated whey protein based films. These films showed a higher tensile strength and were less thick than the control film in the present study, which can be explained by the higher percentage of added glycerol. Moreover, the elongation at break was higher in the film with $50 \%$ of glycerol and higher than the values found for the control and active films conceived in this study. However, the film with $40 \%$ of glycerol showed a lower elongation at break value (3.6\%) than the control film [48] (Table 2). 
The produced films were predominant yellowish, and the incorporation of the best active extract interfered on this optical parameter, which can be visually observed (Figure 2) and confirmed by the measured CIELab coordinates (Table 2). Films incorporated with the extract got darker (increased L, $p<0.05$ ) with a stronger yellow appearance (higher $\mathrm{b}^{*}, p<0.05$ ). A similar behavior was also observed in chitosan films incorporated with hydroalcoholic extracts from different plants (food seasoning herbs and tea) [49] or essential oil [50]. The extracts contribute to add color to the films due to their intrinsic color, and the ability of their active compounds to structurally bind with the polymer, changing the film's optical properties [49]. The active film presented a hue angle around $90^{\circ}$, which corresponds to the yellow color. On the other hand, the control films presented a superior angle (around 102.), which indicates a tendency to the green color (Table 2). These results suggest that the extract potentialize the yellow color in the active films when compared to the control films. Regarding the chromaticity, the extract significantly $(p<0.05)$ increased the films' color saturation, which means that the active film present more vivid colors than the control film [49]. The optical values of the control film were higher than the values of the whey protein film produced by Ribeiro-Santos et al. [26], indicating that the film produced in this study was more shining $(\mathrm{L})$, green $(-a)$ and yellow $(+b)$.

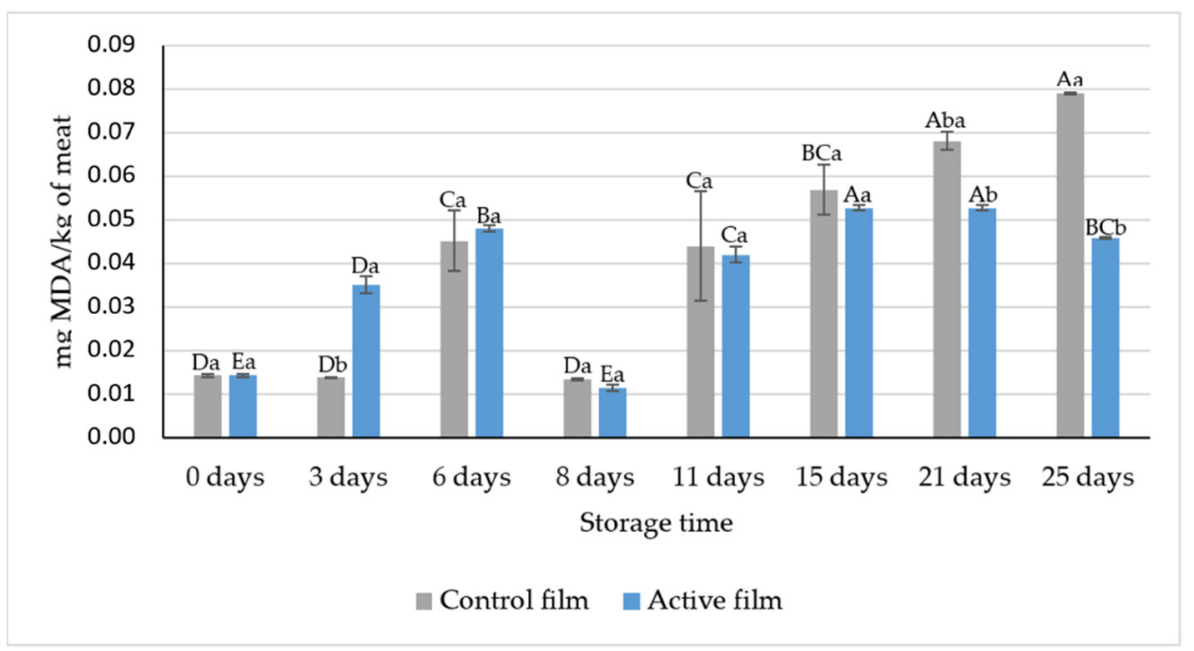

Figure 2. Results of the TBARS assay of the chicken breasts packaged for 25 days with the control and the active films. The results are expressed in $\mathrm{mg}$ of malonaldehyde equivalents per $\mathrm{kg}$ of meat, as means \pm standard deviation of the replicants. (A-E): Within each treatment, values not sharing upper case superscript letters indicate statistically significant differences among days $(p<0.05)$; $(\mathbf{a}-\mathbf{b})$ : Within each storage day, values not sharing lower case superscript letters indicate statistically significant differences among treatment $(p<0.05)$.

\subsubsection{TBARS Assay}

Lipid oxidation is a natural complex phenomenon. Its initiated by the formation of free peroxyl radicals, which will react with unsaturated fatty acids, forming lipid hydroperoxides. Antioxidant compounds may inhibit lipid oxidation of the unsaturated fats by prevent the formation of free peroxyl radicals and the formation of lipid hydroperoxides [51-53].

The TBARS assay is one of the most common methods to evaluate foods' lipid oxidation by measuring the malonaldehyde (MDA) content. MDA is an aldehyde formed during the polyunsaturated fatty acids peroxidation, being a product of the primary oxidation of lipids [32,52-54]. However, this assay only measures substances reactive to the thiobarbituric acid which, during lipid oxidation, will continue to be degraded [32,55]. The results of the TBARS assay are present in Figure 2. For this assay, a calibration curve $(y=308.7 x-0.0071)$ was obtained using 1,1,3,3-tetramethoxypropane as standard. The determination coefficient of the calibration curve was 0.9995, in a working range of $0.1-3 \mu \mathrm{g} / \mathrm{mL}$, indicating linearity and correlation. As can be observed in Figure 2, the 
chicken packaged with the active film for 15, 21 and 25 days of storage, presented a significantly lower MDA value than the chicken packaged with the control film. The decrease of the MDA content on the 8th day of storage seems to suggest that the oxidative status of the chicken breasts reached an oxidation peak between the 6th and the 8th day of storage. Shahbazi and Shavisi [56] also registered the same TBARS behaviour in rainbow trout fillets on the 10th day of storage. This can also be explained by the chemical reactions between MDA and the meat compounds, which may lead to a decrease in the MDA amount [56,57].

Although not conclusively, the study lead by Reboleira et al. [58] showed some inhibition of chicken patties' lipid oxidation when in contact with Porphyra dioica extract for $96 \mathrm{~h}$ (4 days). Gonçalves et al. [59] evaluated the effect of microalgae biopeptides nanofibers in chicken breasts. The authors found that the chicken with the microalgae nanofibers presented a lower MDA value $(1.0 \pm 0.0 \mathrm{mg} \mathrm{MDA} / \mathrm{kg})$ than the control breast chicken $(2.6 \pm 0.0 \mathrm{mg} \mathrm{MDA} / \mathrm{kg})$. The values found in the study of Gonçalves et al. [59] are much higher than the values calculated for the chicken packaging with the whey protein film. The authors studied the influence of polycaprolactone (PCL) nanofibers incorporated with microalgae biopeptides on chicken lipid oxidation. At the end of 12 days of storage, the MDA values were much higher than the values found in this study. However, the MDA content of the chicken meat at day 0 was also higher that the MDA value of the chicken breasts, indicating that the chicken evaluated on this study was 'fresher' [59].

\section{Conclusions}

A whey protein edible film incorporated with an ethanolic extract of Fucus vesiculosus L. was successfully prepared by casting method. The addition of the F. vesiculosus extract seems to reinforce some of the whey protein film physical characteristics, such as thickness, tensile strength, and elastic modulus. However, the addition of the extract made the film more permeable to water vapor. The new film was able to inhibit lipid oxidation of packaged poultry meat, at least for 25 days of storage compared with the control whey protein film. One of the studies limitations was the inability to perform other lipid oxidation assays, such as the determination and quantification of the aldehyde hexanal, responsible for the rancid smell and taste. The determination of the peroxide value is also another lipid oxidation evaluation assay, but the authors were not able to perform this assay in the laboratory. Moreover, the obtained results encourage more assays, namely microbiological assays, and sensorial analysis, in order to evaluate the effect of this new film in the extension of poultry meat shelf-life.

Author Contributions: Conceptualization, S.B., A.L.F., A.S.S. and F.R.; data curation, M.A.A., C.H.B., V.G.L.S. and J.R.; formal analysis, M.A.A., C.H.B. and V.G.L.S.; funding acquisition, S.B., A.L.F., A.S.S. and F.R.; investigation, M.A.A., V.G.L.S., I.M.C., J.R., S.M., A.L.F., F.V. and A.S.S.; methodology, M.A.A. and C.H.B.; project administration, S.B., F.V. and A.S.S.; resources, V.G.L.S. and J.R.; software, M.A.A. and V.G.L.S.; supervision, S.B., A.S.S. and F.R.; validation, M.A.A., V.G.L.S., I.M.C., S.B., R.G., S.M., A.L.F., F.V. and F.R.; writing-review and editing, M.A.A., C.H.B., I.M.C., J.R., S.B., R.G., S.M., A.L.F., F.V., A.S.S. and F.R. All authors have read and agreed to the published version of the manuscript.

Funding: This work was supported by the research project "i.FILM-Multifunctional Films for Intelligent and Active Applications" ( $n^{\circ}$ 17921) cofounded by European Regional Development Fund (FEDER) through the Competitiveness and Internationalization Operational Program under the "Portugal 2020" Program, Call no. 33/SI/2015, Co-Promotion Projects and by the Integrated Pro-gramme of SR\&TD "Smart Valorization of Endogenous Marine Biological Resources Under a Changing Climate" (reference Centro-01-0145-FEDER-000018), co-funded by Centro 2020 program, Portugal 2020, European Union, through the European Regional Development Fund. Mariana Andrade is grateful for her research grant (SFRH/BD/138730/2018) funded by the Fundação para a Ciência e Tecnologia (FCT). João Reboleira is grateful for his research grant (2016/iFILM/BM) in the frame of iFILM project. This work was supported by MEtRICs unit which is financed by national funds from FCT/MCTES (UIDB/04077/2020) and by CECA unit which is financed from FCT/MCTES through national funds (UIDB/00211/2020) [v.souza@campus.fct.unl.pt (V.G.L.S.); ala@fct.unl.pt 
(A.L.F.); ana.silva@iniav.pt (A.S.S.)]. This work was supported by the Associate Laboratory for Green Chemistry-LAQV which is financed by national funds from FCT/MCTES (UIDB/50006/2020 and UIDP/50006/2020).

Institutional Review Board Statement: Not applicable.

Informed Consent Statement: Not applicable.

Data Availability Statement: Not applicable.

Conflicts of Interest: The authors declare no conflict of interest.

\section{References}

1. Balina, K.; Romagnoli, F.; Blumberga, D. Chemical Composition and Potential Use of Fucus Vesiculosus from Gulf of Riga. Energy Procedia 2016, 95, 43-49. [CrossRef]

2. Chapman, V.J.; Chapman, D.J. Sea Vegetables (Algae as Food for Man). In Seaweeds and Their Uses; Springer: Dordrecht, The Netherlands, 1980; pp. 62-97.

3. Agregán, R.; Munekata, P.E.; Franco, D.; Dominguez, R.; Carballo, J.; Lorenzo, J.M. Phenolic compounds from three brown seaweed species using LC-DAD-ESI-MS/MS. Food Res. Int. 2017, 99, 979-985. [CrossRef] [PubMed]

4. Nisizawa, K.; Noda, H.; Kikuchi, R.; Watanabe, T. The main seaweed foods in Japan. Hydrobiologia 1987, 5-29. [CrossRef]

5. Peinado, I.; Girón, J.; Koutsidis, G.; Ames, J. Chemical composition, antioxidant activity and sensory evaluation of five different species of brown edible seaweeds. Food Res. Int. 2014, 66, 36-44. [CrossRef]

6. Chan, C.-C.J.; Cheung, C.-K.P.; Ang, P.O. Comparative Studies on the Effect of Three Drying Methods on the Nutritional Composition of Seaweed Sargassum hemiphyllum (Turn.) C. Ag. J. Agric. Food Chem. 1997, 45, 3056-3059.

7. Robards, K. Strategies for the determination of bioactive phenols in plants, fruit and vegetables. J. Chromatogr. A 2003, 1000, 657-691. [CrossRef]

8. Moreno, S.; Scheyer, T.; Romano, C.S.; Vojnov, A.A. Antioxidant and antimicrobial activities of rosemary extracts linked to their polyphenol composition. Free. Radic. Res. 2006, 40, 223-231. [CrossRef] [PubMed]

9. Spáčil, Z.; Nováková, L.; Solich, P. Analysis of phenolic compounds by high performance liquid chromatography and ultra performance liquid chromatography. Talanta 2008, 76, 189-199. [CrossRef] [PubMed]

10. Dai, J.; Mumper, R.J. Plant Phenolics: Extraction, Analysis and Their Antioxidant and Anticancer Properties. Molecules 2010, 15, 7313-7352. [CrossRef]

11. Stern, J.L.; Hagerman, A.E.; Steinberg, P.D.; Winter, F.C.; Estes, J.A. A new assay for quantifying brown algal phlorotannins and comparisons to previous methods. J. Chem. Ecol. 1996, 22, 1273-1293. [CrossRef]

12. Piccaglia, R.; Marotti, M.; Giovanelli, E.; Deans, S.; Eaglesham, E. Antibacterial and antioxidant properties of Mediterranean aromatic plants. Ind. Crop. Prod. 1993, 2, 47-50. [CrossRef]

13. Sartoratto, A.; Machado, A.L.M.; Delarmelina, C.; Figueira, G.M.; Duarte, M.C.T.; Rehder, V.L.G. Composition and antimi-crobial activity of essential oils from aromatic plants used in Brazil. Braz. J. Microbiol. 2004, 35, 275-280. [CrossRef]

14. Proestos, C.; Sereli, D.; Komaitis, M. Determination of phenolic compounds in aromatic plants by RP-HPLC and GC-MS. Food Chem. 2006, 95, 44-52. [CrossRef]

15. Russell, G. Spatial and environmental components of evolutionary change: Interactive effects of salinity and temperature onFucus vesiculosus as an example. Helgol. Mar. Res. 1987, 41, 371-376. [CrossRef]

16. Saha, M.; Rempt, M.; Grosser, K.; Pohnert, G.; Weinberger, F. Surface-associated fucoxanthin mediates settlement of bacterial epiphytes on the rockweedFucus vesiculosus. Biofouling 2011, 27, 423-433. [CrossRef] [PubMed]

17. Díaz-Rubio, M.E.; Pérez-Jiménez, J.; Saura-Calixto, F. Dietary fiber and antioxidant capacity in Fucus vesiculosus products. Int. J. Food Sci. Nutr. 2009, 60, 23-34. [CrossRef] [PubMed]

18. Tuccilli, C.; Baldini, E.; Truppa, E.; D’Auria, B.; De Quattro, D.; Cacciola, G.; Aceti, T.; Cirillo, G.; Faiola, A.; Indigeno, P.; et al. Iodine deficiency in pregnancy: Still a health issue for the women of Cassino city, Italy. Nutrition 2018, 50, 60-65. [CrossRef]

19. World Health Organizatio. Towards the Elimination of Iodine Deficiency by 2020. Available online: http://www.who.int/ nutrition/events/2017-elimination-idd-2020-side-events-23May/en/ (accessed on 15 September 2020).

20. Vanderpas, J.B.; Moreno-Reyes, R. Historical aspects of iodine deficiency control. Minerva Med. 2017, 108, 124-135. [PubMed]

21. Moro, C.; Basile, G. Obesity and medicinal plants. Fitoterapia 2000, 71, S73-S82. [CrossRef]

22. Dainelli, D.; Gontard, N.; Spyropoulos, D.; Beuken, E.Z.-V.D.; Tobback, P. Active and intelligent food packaging: Legal aspects and safety concerns. Trends Food Sci. Technol. 2008, 19, S103-S112. [CrossRef]

23. Food Packaging Technology; Coles, R.; McDowell, D.; Kirwan, M.J. (Eds.) Blackwell Publishing Ltd.: Hoboken, NJ, USA, 2003; ISBN 9780520072817.

24. Sebti, I.; Delves-Broughton, J.; Coma, V. Physicochemical Properties and Bioactivity of Nisin-Containing Cross-Linked Hydroxypropylmethylcellulose Films. J. Agric. Food Chem. 2003, 51, 6468-6474. [CrossRef]

25. Galstyan, V.; Bhandari, M.P.; Sberveglieri, V.; Sberveglieri, G.; Comini, E. Metal Oxide Nanostructures in Food Applications: Quality Control and Packaging. Chemosensors 2018, 6, 16. [CrossRef] 
26. Ribeiro-Santos, R.; De Melo, N.R.; Andrade, M.; Azevedo, G.; Machado, A.V.; Carvalho-Costa, D.; Sanches-Silva, A. Whey protein active films incorporated with a blend of essential oils: Characterization and effectiveness. Packag. Technol. Sci. 2018, 31, 27-40. [CrossRef]

27. Ribeiro-Santos, R.; Andrade, M.; Madella, D.; Martinazzo, A.P.; Moura, L.D.A.G.; De Melo, N.R.; Sanches-Silva, A. Revisiting an ancient spice with medicinal purposes: Cinnamon. Trends Food Sci. Technol. 2017, 62, 154-169. [CrossRef]

28. Gutiérrez, J.B. Ciencia Bromatológica: Principios Generales de los Alimentos; Ediciones Díaz de Santos: Madrid, Spain, 2000.

29. Márquez-Ruiz, G.; García-Martínez, M.; Holgado, F. Changes and Effects of Dietary Oxidized Lipids in the Gastrointestinal Tract. Lipid Insights 2008, 2, LPI.S904. [CrossRef]

30. Mariutti, L.R.; Bragagnolo, N. Influence of salt on lipid oxidation in meat and seafood products: A review. Food Res. Int. 2017, 94, 90-100. [CrossRef]

31. Andrade, M.A.; Ribeiro-Santos, R.; Guerra, M.; Sanches-Silva, A. Evaluation of the Oxidative Status of Salami Packaged with an Active Whey Protein Film. Foods 2019, 8, 387. [CrossRef]

32. Castro, F.V.R.; Andrade, M.A.; Sanches Silva, A.; Vaz, M.F.; Vilarinho, F. The Contribution of a Whey Protein Film Incorpo-rated with Green Tea Extract to Minimize the Lipid Oxidation of Salmon (Salmo salar L.). Foods 2019, 8, 327. [CrossRef]

33. Vilarinho, F.; Andrade, M.; Buonocore, G.G.; Stanzione, M.; Vaz, M.F.; Silva, A.S. Monitoring lipid oxidation in a processed meat product packaged with nanocomposite poly(lactic acid) film. Eur. Polym. J. 2018, 98, 362-367. [CrossRef]

34. Brody, A.L.; Strupinsky, E.R.; Kline, L.R. Ative Packaging for Food Applications; CRC Press: Boca Raton, FL, USA, 2001.

35. Silva, A.S.; Freire, J.M.C.; Franz, R.; Losada, P.P. Mass transport studies of model migrants within dry foodstuffs. J. Cereal Sci. 2008, 48, 662-669. [CrossRef]

36. Umaraw, P.; Munekata, P.E.; Verma, A.K.; Barba, F.J.; Singh, V.; Kumar, P.; Lorenzo, J.M. Edible films/coating with tailored properties for active packaging of meat, fish and derived products. Trends Food Sci. Technol. 2020, 98, 10-24. [CrossRef]

37. Andrade, M.A.; Ribeiro-Santos, R.; Bonito, M.C.C.; Saraiva, M.; Sanches-Silva, A. Characterization of rosemary and thyme extracts for incorporation into a whey protein based film. LWT 2018, 92, 497-508. [CrossRef]

38. Miller, H.E. A simplified method for the evaluation of antioxidants. J. Am. Oil Chem. Soc. 1971, 48, 91. [CrossRef]

39. Wang, T.; Jónsdóttir, R.; Liu, H.; Gu, L.; Kristinsson, H.G.; Raghavan, S.; Ólafsdóttir, G. Antioxidant Capacities of Phlorotan-nins Extracted from the Brown Algae Fucus vesiculosus. J. Agric. Food Chem. 2012, 60, 5874-5883. [CrossRef] [PubMed]

40. ASTM-America Society Standard Testing and Materials. Standard Test Method for Tensile Properties of Thin Plastic Sheeting; D882-12; ASTM: West Conshohocken, PA, USA, 2012.

41. Sarantópoulos, C.; Oliveira, L.; Padula, M.; Coltro, L.; Alves, R.; Garcia, E. Embalagens Plásticas Flexíveis- Principais Polímeros e Avaliação de Propriedades; ITAL: Campinas, Brazil, 2002.

42. Ferreira, A.R.; Torres, C.A.; Freitas, F.; Sevrin, C.; Grandfils, C.; Reis, M.A.; Alves, V.D.; Coelhoso, I.M. Development and characterization of bilayer films of FucoPol and chitosan. Carbohydr. Polym. 2016, 147, 8-15. [CrossRef] [PubMed]

43. Rosmini, M.R.; Perlo, F.; A Pérez-Alvarez, J.; Pagán-Moreno, M.J.; Gago-Gago, A.; López-Santoveña, F.; Aranda-Catalá, V. TBA test by an extractive method applied to 'paté'. Meat Sci. 1996, 42, 103-110. [CrossRef]

44. Argyropoulos, D.; Müller, J. Effect of convective-, vacuum- and freeze drying on sorption behaviour and bioactive compounds of lemon balm (Melissa officinalis L.). J. Appl. Res. Med. Aromat. Plants 2014, 1, 59-69. [CrossRef]

45. Dos Santos, M.A.Z.; Alicieo, T.V.R.; Pereira, C.M.P.; Ramis-Ramos, G.; Mendonça, C.R.B.; Dos Santos, M.A.Z. Profile of Bioactive Compounds in Avocado Pulp Oil: Influence of the Drying Processes and Extraction Methods. J. Am. Oil Chem. Soc. 2013, 91, 19-27. [CrossRef]

46. Fernandes, L.M.; Guimarães, J.T.; Silva, R.; Rocha, R.S.; Coutinho, N.M.; Balthazar, C.F.; Calvalcanti, R.N.; Piler, C.W.; Pimentel, T.C.; Neto, R.P.; et al. Whey protein films added with galactooligosaccharide and xylooligosaccharide. Food Hydrocoll. 2020, 104, 105755. [CrossRef]

47. Gounga, M.E.; Xu, S.-Y.; Wang, Z. Whey protein isolate-based edible films as affected by protein concentration, glycerol ratio and pullulan addition in film formation. J. Food Eng. 2007, 83, 521-530. [CrossRef]

48. Abdalrazeq, M.; Giosafatto, C.V.L.; Esposito, M.; Fenderico, M.; Di Pierro, P.; Porta, R. Glycerol-Plasticized Films Obtained from Whey Proteins Denatured at Alkaline pH. Coatings 2019, 9, 322. [CrossRef]

49. Souza, V.G.L.; Fernando, A.L.; Pires, J.R.A.; Rodrigues, P.F.; Lopes, A.A.; Fernandes, F.M.B. Physical properties of chitosan films incorporated with natural antioxidants. Ind. Crop. Prod. 2017, 107, 565-572. [CrossRef]

50. Souza, V.G.L.; Pires, J.R.A.; Rodrigues, C.; Rodrigues, P.F.; Lopes, A.; Silva, R.J.; Caldeira, J.; Duarte, M.P.; Fernandes, F.B.; Coelhoso, I.M.; et al. Physical and Morphological Characterization of Chitosan/Montmorillonite Films Incorporated with Ginger Essential Oil. Coatings 2019, 9, 700. [CrossRef]

51. Guerreiro, A.; Andrade, M.A.; Menezes, C.; Vilarinho, F.; Dias, E. Antioxidant and Cytoprotective Properties of Cyanobacteria: Potential for Biotechnological Applications. Toxins 2020, 12, 548. [CrossRef]

52. Miller, D.D. Food Chemistry: A Laboratory Manual, 2nd ed.; Wiley: Hoboken, NJ, USA, 1998.

53. Osawa, C.C.; De Felício, P.E.; Gonçalves, L.A.G. Teste de TBA aplicado a carnes e derivados: Métodos tradicionais, modificados e alternativos. Química Nova 2005, 28, 655-663. [CrossRef]

54. Ross, C.F.; Smith, D.M. Use of Volatiles as Indicators of Lipid Oxidation in Muscle Foods. Compr. Rev. Food Sci. Food Saf. 2006, 5 , 18-25. [CrossRef] 
55. Dasgupta, A.; Klein, K. Methods for Measuring Oxidative Stress in the Laboratory. In Antioxidants in Food, Vitamins and Supplements; Elsevier BV: Amsterdam, The Netherlands, 2014; pp. 19-40.

56. Shahbazi, Y.; Shavisi, N. Chitosan Coatings Containing Mentha spicata Essential Oil and Zinc Oxide Nanoparticle for Shelf Life Extension of Rainbow Trout Fillets. J. Aquat. Food Prod. Technol. 2018, 27, 1-12. [CrossRef]

57. Khezrian, A.; Shahbazi, Y. Application of nanocompostie chitosan and carboxymethyl cellulose films containing natural preservative compounds in minced camel's meat. Int. J. Biol. Macromol. 2018, 106, 1146-1158. [CrossRef]

58. Reboleira, J.; Adão, P.; Guerreiro, S.F.C.; Dias, J.R.; Ganhão, R.; Mendes, S.; Andrade, M.; Vilarinho, F.; Sanches-Silva, A.; Mateus, A.; et al. Poultry Shelf-Life Enhancing Potential of Nanofibers and Nanoparticles Containing Porphyra dioica Extracts. Coatings 2020, 10, 315. [CrossRef]

59. Gonçalves, C.F.; Schmatz, D.A.; Uebel, L.D.S.; Kuntzler, S.G.; Costa, J.A.V.; Zimmer, K.R.; de Morais, M.G. Microalgae Biopeptides Applied in Nanofibers for the Development of Active Packaging. Polimeros 2017, 27, 290-297. [CrossRef] 